\title{
Editorial: The Invertebrate Antibody: Plagiarism?
}

\author{
Michel Leclerc
}

Immunology of Invertebrates, 556 rue Isabelle Romée 45640 Sandillon (France)

*Corresponding Author: Michel Leclerc, Immunology of Invertebrates, 556 rue Isabelle Romée 45640 Sandillon (France).

\section{INTRODUCTION}

Many researchers don't believe in our works: they speak we are wrong when we evoke the Invertebrate Antibody...BUT Nabanita Murkherjee + shamelessly plagiarizes us in an article which was published in 2020. The title was: «The Invertebrate Antibody-Sea star Lymphocytes »

She wrote:

"We have discovered, in the past, the sea star lymphocytes (B and T sea star lymphocytes: cf Fig 1,2$)$ : these cells of $4-5 \mu$ in diameter are smaller than Vertebrate lymphocytes

And ...We discovered recently the IPA (Invertebrate Primitive Antibody) with the sea star IGKAPPA gene with IG sites (Meta Gene 2013).

Therefore genomic data assert the evidence of primitive antibody in Echinodermata.

Furthermore, we find MHC genes class I and class II in 2019 and Fab gene, Fc receptor gene in these Invertebrates »

To day we envisage Immunology with a new light. IT'S TIME TO EVOLVE! We have a sea star Igkappa gene:

The sea star Igkappa gene is very high in the phylogeny of the immune system of animals.
It shows already two Ig sites! The forms of Igkappa genes are all found in vertebrates, they share many details with the sea star, including the presence of Ig sites.

The preservation of the Igkappa gene in treated and not treated sea stars is an excellent opportunity for further experiments. It is important to notice that the Igkappa chain V-III region HAH of Tupaia chinensis is situated (in the assumptions behind the theory of evolution) between the Igkappa chain precursor V-II region (RPMI/133) and Igkappa chain precursor V-IV region/121.

Additionally, the existence of members of the IgKappa gene family with conserved functional characters, indicate that the sea star IgKappa gene has evolved prior to the evolutionary divergence between Invertebrate and Vertebrates: It must be claimed.

On the other hand, the discovery of a Fc receptor gene, of a Fab gene, in Asterias rubens genome of MHC genes, corroborate the presence of the primitive Invertebrate antibody in asterids (IPA)

Finally we think we did a good job.

+Nabanita Murkherzee belongs to the Department of Dermatology. University of Colorado (USA)

Fig.1

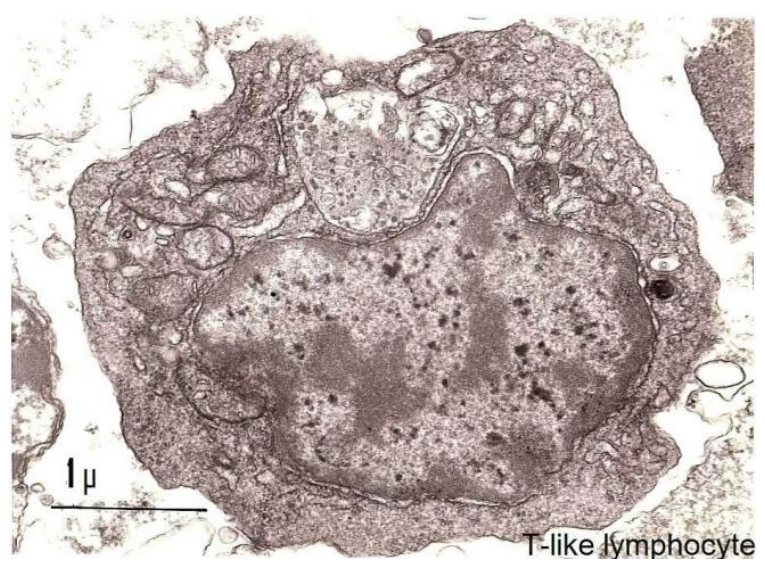


Editorial: The Invertebrate Antibody: Plagiarism?

Fig.2

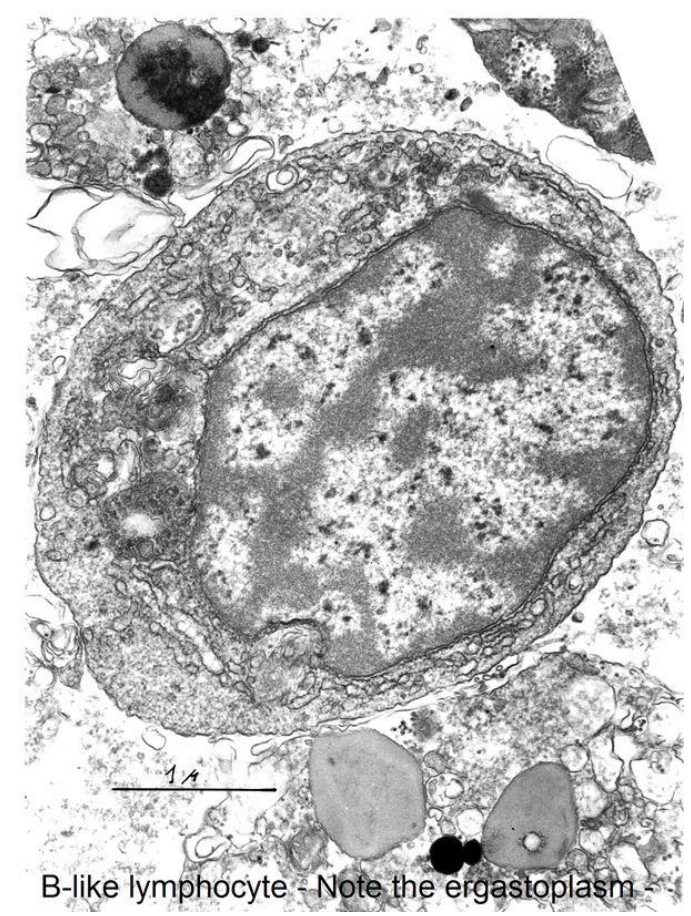

Citation: Michel Leclerc, “Editorial: The Invertebrate Antibody: Plagiarism?”, International Journal of Research Studies in Medical and Health Sciences. 2020; 5(9): 29-30.

Copyright: (c) 2020 Michel Leclerc, This is an open-access article distributed under the terms of the Creative Commons Attribution License, which permits unrestricted use, distribution, and reproduction in any medium, provided the original author and source are credited. 